\title{
Theoretical Framework of Foreign Exchange Exposure, Competition and the Market Value of Domestic Corporations
}

\author{
Abubaker Alssayah ${ }^{1}$ \& Professor Chandrasekhar Krishnamurti ${ }^{1}$ \\ ${ }^{1}$ School of Accounting, Economics and Finance, Faculty of Business and Law, University of Southern \\ Queensland (USQ), Australia \\ Correspondence: Abubaker Alssayah, School of Accounting, Economics and Finance, Faculty of Business and \\ Law, University of Southern Queensland (USQ), Australia. E-mail: alssayah1@gmail.com \& \\ Abubaker.Alssayah@usq.edu.au
}

Received: November 17, 2012

Accepted: January 2, $2013 \quad$ Online Published: January 8, 2013

doi:10.5539/ijef.v5n2p1

URL: http://dx.doi.org/10.5539/ijef.v5n2p1

\begin{abstract}
The purpose of this study is to examine the foreign exchange rate exposure of domestic corporations in the United Arab Emirates (UAE) and the implications of that exposure for the market value of those corporations, considering the effect of competition as a determinant of exchange rate exposure. The justification for this study is that the UAE has an open economy with a high per capita income and a sizable annual trade surplus. In addition, the World Economic Forum issued its Global Competitiveness report for the year 2010-2011 in which the UAE was the only Arab country that was included in the elite club of countries that have shown an increment in endorsing new and improved methods for developing their economies. However, because of the indirect nature of foreign exchange rate exposure for local or domestic firms, the managers of these firms are unwilling to engage in hedging activities that may mitigate exchange rate exposure. A change in prices, the cost of final goods, the cost of raw material, labor costs or the costs of input or output and other substitute goods due to fluctuating exchange rates may have an adverse effect on the competitive position of a local or domestic firm with no international and foreign activities. The outcomes of this study will determine whether the domestic firms are exposure to the fluctuation of foreign exchange rates.
\end{abstract}

Keywords: exchange rate exposure, foreign exchange risk, determinants of exchange rate exposure

\section{Introduction}

The purpose of this study is to examine the foreign exchange rate exposure of domestic corporations in the United Arab Emirates (UAE) and the implications of that exposure for the market value of those corporations. The starting points for this study is the questions left unanswered by the most recent literature in this field of finance, especially that of Aggarwal and Harper (2010). These authors attempt to fill an important gap in the literature by examining the nature and causes of foreign exchange rate exposure of domestic firms. These firms are not generally considered to bear foreign exchange risk and, to date, they had not been studied in the literature. This study contributes to the literature by augmenting the Aggarwal and Harper (2010) model and extending its application to the UAE. Specifically, although Aggarwal and Harper (2010), like Williamson (2001), consider 'competition' as a determinant of foreign exchange rate exposure, their approach to measuring this variable uses a methodology that has been questioned in economic literature. By augmenting the Aggarwal and Harper (2010) model by explicitly incorporating an alternative measurement methodology for 'competition' into a model of foreign exchange exposure and by applying the model to a new context (UAE) where domestic corporations have not traditionally considered their FX exposure and where there are limited foreign exchange hedging activities. This study aims to contribute to our understanding of the determinants of foreign exchange rate exposure of domestic corporations. The study takes one additional step by examining the implications of foreign exchange exposure for the market value of domestic corporations. This, of course, is of paramount interest to investors and the corporate financial managers charged with the task of creating market value.

\section{Background}

Modern finance and economics have been concerned with the effects of changes in exchange rates on returns and cash flows of corporations (Aggarwal \& Harper 2010). After the collapse of the Bretton Woods System in the mid-1970s, most corporations throughout the world viewed exchange rates as significant risk factor (Bartram 
2008). This is especially the case in those industries that have been subject to substantial globalisation (Bartram et al. 2010). The changes in exchange rates have an impact on domestic and international corporations that can be defined as the 'exposure' of the corporation to fluctuating foreign exchange rates. The exposure to foreign exchange rate fluctuations usually manifests itself as an impact on: (i) 'the value of net monetary assets with fixed nominal payoffs' and (ii) the value of real assets held by the firm' (Jorion 1990, p. 333).

\section{How Corporations Are Exposed to Foreign Exchange Fluctuations}

Corporations are exposed to the risk of changing exchange rates through many channels. For example, if a firm relies on international or cross-border sales, the firm exposes itself to the risk of foreign exchange rate fluctuations. The change in exchange rates will have an impact on the value of international sales revenue. However, exposure to exchange rates can be decreased or managed. For example, if the firm sources raw materials from abroad or any cross-border location, it can ensure that its imports and exports are both in the same currency.

Generally, however, such a type of firm may have assets and liabilities at various cross-border locations. This can play a vital role in increasing the firm's exposure to changing exchange rates. Furthermore, it should be noted that it is not necessarily only those firms involved in exporting or importing activities or are classified as multinational corporations that have exposure to changing exchange rates. Local companies, firms and corporations that do not have any international revenue or are not involved in cross-border sales may also be impacted by changing exchange rates, possibly indirectly through their competition with other importing companies (Jong et al. 2006).

\section{Implications of Foreign Exchange Rate Exposure}

Researchers continue their efforts to understand the determinants and level of exposure to changing exchange rates for corporations because of the implications for business activity of FX risk and the difficulty in predicting fluctuations in foreign exchange markets (Salifu et al. 2007). Empirical research indicates that volatile exchange rates affect the revenue and profits of both multinational and local corporations (Muller \& Verschoor 2006). Because of the prevalence of outsourcing activities to foreign countries, corporations incur costs in foreign currency (e.g., wages, taxes and material) and it is important for corporate financial managers to be aware of the extent of this exposure (Abor 2005). Furthermore, corporations not involved in foreign exchange trades or outsourcing activities are also exposed to the fluctuating exchange rates through competition with multinational organisations, foreign competitors, and macroeconomic conditions. Therefore, many local and multinational organisations find their income statements and business performance affected by fluctuating exchange rates, in spite of their having only indirect financial exposure (Parsley \& Popper 2006).

A change in prices, the cost of final goods, the cost of raw material, labor costs or the costs of input or output and other substitute goods due to fluctuating exchange rates may have an adverse effect on the competitive position of a local or domestic firm with no international and foreign activities. Theory and empirical work in financial economics suggests that the exposure of a firm to changing exchange rates depends on the type of product and the nature of the competitive environment in which the firm operates (Bradley \& Moles 2001). The general concept of exposure is the level of impact on the net worth of a firm due to fluctuating exchange rates (El-Masry 2006).

\section{Case Study: United Arab Emirates}

During 1962, when the United Arab Emirates (UAE) discovered oil within its region, the economy of the UAE increased significantly. The inflow of funds from oil sales provided money to establish and develop economic activities. In addition, fundamental structural reforms, together with liberal and market-oriented policies, have fostered the rapid expansion of the non-oil economy with a well-integrated trading system that has also encouraged the participation of the private sector. The non-oil export structure of the UAE has been improved to engage in the production of more diversified products such as transport equipment and light machinery (mainly from the free zone exports (Note 1)). This development was due primarily to a dependence based on domestic industry such as cement, fertilizers, petrochemicals and financial industries. The basket of trade collected by the UN shows that the UAE has performed well in products such as consumer electronics, basic manufacturing and IT. In addition, employment in the non-oil sector has increased to about $8.7 \%$ (Mohamad Elhage 2005).

The World Economic Forum issued its Global Competitiveness Report for the year 2010-2011 in which the UAE was the only Arab country that was included in the elite club of countries that have shown an increment in endorsing new and improved methods for developing their economies. It is the second time that the UAE has been included in the "Innovation-driven economies" category, alongside global power houses such as Germany, 
Sweden, Japan, Australia, Canada, Switzerland, the USA, the UK and Singapore. The UAE was ranked 25th in this report for having been active in enhancing its economy through innovative ideas (Sala-i-Martin et al. 2010).

The justification for choosing the UAE for this study is that the UAE has an open economy with a high per capita income and a sizeable annual trade surplus. The successful economic efforts of the UAE diversification have reduced the portion of GDP based on oil and gas output to $25 \%$. A boost has been given to the private sector by providing greater economic provisions by the government - which has also increased its budget allocation for the creation of more jobs and infrastructure development (CIA 2011). Foreign trade constitutes an important factor in economic activity in the UAE and confirms the UAE is an open economy. For instance, the proportion of exports and imports to GDP in UAE exceeds unity for every year during the 1990s compared to the US at less than 0.25 in the same period (Darrat \& Al-Yousif 2003). In addition, the main aim of this study is to investigate how changes in foreign exchange rates affect the competitiveness of domestic firms in developing countries. In this case, this study focuses on a developing country that has a high rank of competitiveness globally. Moreover, in the Global Competitiveness Report, the UAE has received a high ranking for competitiveness and has been included in the elite club of countries exhibiting an increment in endorsing new and improved methods for developing their economies.

\section{Study Motivation}

This study is motivated by ongoing concerns about the impact of foreign exchange rate exposure on the value of returns of domestic firms in the UAE. More specifically, this research is motivated by concerns about the increased foreign exchange risk faced by firms after the global financial crisis and the lack of research into the foreign exchange exposure of domestic firms operating in developing countries such as the UAE. Kolasa, Rubaszek and Taglioni (2010) have indicated that most countries have experienced adverse effects of world trade contraction, even firms in countries that have avoided the worst of the financial crisis. According to Melvin and Taylor (2009), exchange rates have experienced a record level of unpredictability. Corporate non-financial managers of domestic UAE firms who ignore the risks associated with foreign exchange when sales and purchases are made solely in their local market may expose their business and their shareholders to substantial risks.

\section{Scope of the Study}

The main objective of this study is to focus on the determinants of the exchange rate exposure of non-financial domestic UAE firms and the effect of that exposure on the value of domestic firms, considering the effect of competition as a determinant of exchange exposure. This study will focus on the main market of the UAE. The sample for this study will be 111 domestic firms listed on the main market of UAE between 2005 and 2011 for monthly data (84 months). In addition, this study will focus only on firms with sales and purchases in the local market (i.e., domestic corporations).

\section{Literature Review}

This literature review is organised as follows. First, those studies that have examined the effect of exchange rate exposure on the value of firms are reviewed. Second, the empirical work that has investigated the determinants of exchange rate exposure is appraised. Third, the theoretical and empirical work that has considered 'competition' as a determinant of exchange rate exposure is reviewed. Fourth, the empirical studies that have examined the approaches that corporate financial managers take to manage foreign exchange rate risks are evaluated. The literature review generates several important conclusions: 


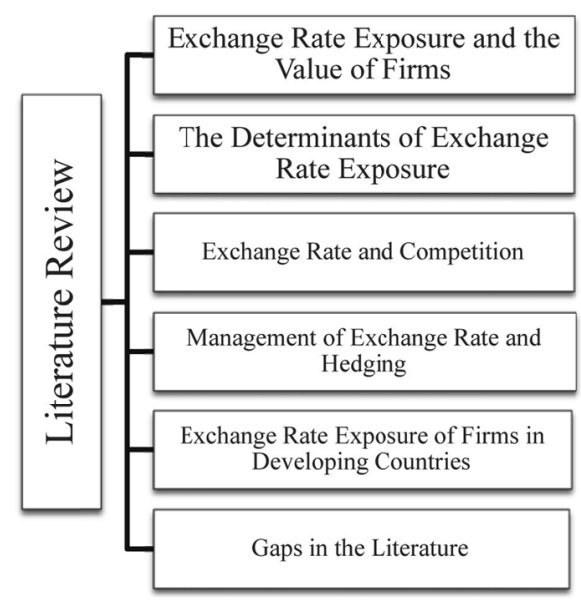

Conceptual diagram of literature review

a. Exchange rate exposure (or FX risk), if not appropriately managed, may have significant adverse effects on the business performance and market value of corporations.

b. Several determinants of exchange rate exposure have been identified.

c. Although 'competition' has been identified as a determinant of exchange rate exposure, the methodology that has been applied to measuring competition in the existing investigations into the exchange rate exposure of domestic corporations (most notably Aggarwal and Harper 2010) suffers from shortcomings.

d. Although corporate financial managers have several (or more) options or tools that can be used to manage exchange rate exposure, corporate financial managers of domestically-focused corporations tend to overlook the importance of exchange rate exposure.

e. To date, there have been limited studies on the exchange rate exposure of domestic corporations in the UAE. This study promises to increase our understanding of the exchange rate exposure of these corporations and, in so doing, contribute further to our understanding of the determinants of exchange rate exposure of domestic corporations.

\subsection{Exchange Rate Exposure and the Value of Firms}

This part of the literature review focuses on those studies that have examined the impact of FX rate exposure on firm value. He and Ng (1998) investigated the influence of fluctuations in the exchange rate on the value of multinational Japanese corporations. In all, 171 multinational Japanese organisations were examined, of which 25\% experienced significant positive exposure effects from January 1979 to December 1993. Choi and Prasad (1995) explored and estimated a model of exchange rate risk exposure and the individual firm's value. Stock return data of 409 US multinational firms from 1978 to 1989 was the basis of this model. Choi and Prasad found that nominal and real exchange rates affect a firm's value. Gao (2000) conducted another similar study in which the prime focus was on multinationals in the manufacturing industry that have operations in foreign countries. An effect by profitability from exchange rate news appears in the stock market based on Gao's experimental results, in which 80 multinationals from the United States were taken from the 3-digit SIC of manufacturing industries. Fraser and Pantzalis (2004) examined the correlation between stock prices and changes in foreign exchange rates for 310 multinational US corporations. Exposure was found to be negatively correlated with the market value of corporations.

According to De Jong et al (2006), some studies have failed to find a strong association between the firms' returns on the stock markets (and, therefore, market value) and fluctuations in the exchange rates. Jorion (1990), Bodnar and Gordon (1993) and Bartov and Bodnar (1994, 1995) found very little evidence concerning the relationship between stock prices and the value of the US dollar. Among these, Jorion (1990) was interested more in the relationship between the firm's stock returns and exchange rate changes. He assessed 287 multinational non-oil-based companies to see whether stock returns changed with the trade-weighted exchange rate over the period from January 1971 to December 1987. His results suggest that only about 5\% of the sample firms showed a significant relationship between stock returns and exchange rate fluctuations. 


\subsection{The Determinants of Exchange Rate Exposure}

Shapiro (1975) devised a two-country model with a focus on profitability. First, he focuses on the characteristics and then examined the bi-national maximising profit strategy of oligopolistic firms, under the influence of the reduction of values and inflation. The principal conclusions in his paper are that one of the main factors influencing companies' exchange rate risk is its sales distribution in foreign and domestic markets. The domestic competition that the multinational firm undergoes amid the influences of imported and local production is another vital factor for exchange risk. Shapiro's (1975) model also implies that in the case of depreciation of the local currency, a value increase in the domestic firm will occur, along with a decrease in the foreign value with which it competes.

Shapiro (1975) devised a two-country model with a focus on profitability. First, he focused on the characteristics and then examined the bi-national maximising profit strategy of oligopolistic firms under the influence of the reduction of values and inflation. The principal conclusions in his paper are that one of the main factors influencing companies' exchange rate risk is their sales distribution in foreign and domestic markets. The domestic competition that the multinational firm undergoes amid the influences of imported and local production is another vital factor for exchange risk. Shapiro's (1975) model also implies that in the case of depreciation of the local currency, a value increase in the domestic firm will occur, along with a decrease in the foreign value with which it competes.

Following Shapiro's early study, many investigations were undertaken into the determinants of exchange rate exposure. For example, Pantzalis, Simkins and Laux (2001) investigated the effects of operational hedges on US multinational companies and their exchange rate exposure. They found strong evidence that the firm's ability to build operational hedges is measured by determinants (e.g., breadth and depth of MNC network ) that affect the firm's exchange rate risk exposure. Dominguez and Tesar (2006) argue that firm features like size of the firm and its affiliation with an industry are correlated with exposure. He and $\mathrm{Ng}$ (1998) found that companies that are less exposed to movements in exchange rates are those with short-term liquidity, high financial leverage, and well-defined hedging activities.

Dominguez and Tesar (2006) studied the connection between the exchange rate and the firm value. The exchange rate exposure of firms publicly listed was observed in 8 countries in both industrialised and emerging markets. The results indicated the link between exposure and other variables such as the size of the firm, its position in the multinational market, foreign trade and transaction, international assets, and ability to compete according to the industrial standard as indicated by an example of their regression where exposure was observed more in small firms compared to large and medium firms. Moreover, exposure was also observed in firms with international activity dependent on multinational status, international assets, and foreign sales holdings.

$\mathrm{He}$ and $\mathrm{Ng}$ (1998) examined the determinants of exposure and found that the estimated exposure is directly affected by the organisation's export ratio level. They also found that this exposure is linked to other factors that are the proxies for the organisation's hedging incentives. Therefore, they were able to explore the effects on the foreign exchange rate by observing variables such as stock returns, ratio of debt and ratio of dividend payout. These variables also include equity value, ratio of organisation's export and the organisation's size. By using this approach, He and $\mathrm{Ng}$ were able to explain the possibility of an organisation's variables that are proxies for an organisation's hedging activity by its exposure to foreign exchange. Gradually these types of studies identified those factors that determine the exposure of companies to foreign exchange risk. Research conducted by Doidge, Griffin and Williamson (2002) produced similar findings to He and $\mathrm{Ng}$ (1998). These authors established that large firms are more sensitive to currency movements than small firms.

Similar variables were utilised by Géczy, Minton and Schrand (1997) and Aabo, Høg and Kuhn (2010) to identify the risks involved in foreign currency exposure from variables such as foreign activities, foreign debt or an increased concentration of foreign competitors in their industries. The firms' size, R\&D expenditures, export and import ratio, amount of profit and firm's debt were also identified in this exposure. Firms with a higher R\&D expenditure are more likely to hedge because of the increased probability of competition and financial distress. Opler and Titman (1994) found that customers would be more reluctant to engage with firms spending more on $R \& D$ owing to their perception that a high $R \& D$ expenditure means that the firms are specialised in certain products.

Aggarwal and Harper (2010) conducted an important study in the literature that is consistent with this study; these researchers measured and determined exchange rate exposure for a sample of domestic firms. They used the average of the suitable financial factors for the previous years of each firm to evaluate the financial and operational strength and the possibility of reducing exposure. They explained that firms with increased levels of 
debt and financial risks and leverage are more likely to face additional risks and should indicate a positive connection to the exposure of foreign exchange. Firms with higher gross margins enjoy more in elasticity in the pricing of their products and services.

Another important determinant that is consistent with this study is competition. For example, Deshapiro (1975), Dominguez and Tesar (2006), Marston (2001), Luehrman (1990) and Williamson (2001) argue that the amount of domestic and foreign competition export sales, and the substitutability in using domestic or foreign inputs are all determinants of exposure.

\subsection{Exchange Rate and Competition}

To date, an important determinant of exchange rate exposure has been overlooked. This determinant is 'competition'. Movements in exchange rates can have an impact on a company's values through different channels whether or not they have foreign operations. In addition, movements in exchange rates can also affect domestic companies that do not operate in the international market but face international competition in their local market or are indirectly exposed. For example, they may be importing raw materials from suppliers who use foreign material used by domestic companies (Dominguez \& Tesar 2006). Marston (2001) emphasised that a domestic firm (i.e., one that neither imports nor exports) can also experience changes in value when changes in the exchange rate occur. This domestic firm may compete with overseas firms in the local market or may have input purchases that are highly dependent on the exchange rates.

Marston (2001) argues that the exchange rate exposure of an organisation is a function of the net revenues and demand elasticity of the products by the firm and the firm's competitors in the foreign market, as well as the domestic market and location of production. In addition, it can be concluded that a firm facing elevated standards of competition will also have elevated demand elasticity. According to Géczy, Minton and Schrand (1997), variations in the firm's short-term cash flow depends on changes in exchange rates. These changes can be affected by foreign competition which, in turn, may affect the market prices and the demand for domestic output.

Bradley and Moles (2001) attempted to establish the degree to which exchange rate exposure can be linked with industry association. They assume that companies within a particular industrial grouping share a similar competitive position and, in particular, are largely involved in importing, exporting, or competing domestically with foreign-based competitors to the same extent. Utilities, services, consumer goods, general industries and mineral extraction are the five basic categories in which the companies in the survey have been classified. The findings have identified substantial deviation in sensitivities throughout the different industries in question. Thus, the magnitude of deviation highlights the need and importance of evaluation of firms while considering their markets and industries type, rather than aggregating all firms.

Williamson (2001) explored the effects of exposure to changes in the real exchange rate with regard to the industry value of automotive firms. The role played by industry competition and structure in the relationship between the value of firms and the exchange rate exposure were taken into consideration. The automotive industry was used because it is an industry in which high levels of foreign competition are present and in which firms face high elasticity of demand. The companies compete with each other not only on the local level, but also on the international level; therefore, competition between companies, along with the financial health of the company, impacts on the risk a company faces in each country.

\subsection{Management of Exchange Rate and Hedging}

Exchange rate exposure has become an important issue for domestic and foreign firms. Companies need to develop strategies of risk management using operational hedges and financial derivatives (Allayannis et al. 2001). Risk management is critical and has been an important focus in many recent surveys. The prominence of risk management can be observed through the importance assigned to it by financial researchers and practitioners. Knowledge of risk management helps in providing managers with a formula to design hedging strategies (Froot et al. 1993). In addition, the existing research acknowledges the importance of hedging in determining exposure to exchange rates. Bartov and Bodnar (1994) argue that a systematic error is likely to be made by investors when characterising the relation between the firm's value and exchange rate changes. Personnel may not be fully aware of the firm's procedures in hedging foreign currency exposures.

Bodnar, William, and Gordon (1993) conjecture that hedging activities could have led to the minute success in finding considerable exchange rate exposure for industries situated in the United States, Japan and Canada. The tests are based on the assumption that hedging is an incomplete factor that cannot be observed due to the availability of incomplete data on hedging by industries. 
According to the observations made by Allayannis and Ofek (1997), exchange rate exposures are found to have less effect on the hedging activities of large organisations. In the case of small businesses (mostly importers), a positive effect of foreign exchange exposure is found. Nevertheless, hedging is more common in large organisations than small organisations as evident in the studies.

A study by Elliott et al (2003) used US multinational companies as a sample and studied their foreign debt denomination in relation to the foreign currency exposure and its derivative use. The data revealed that the foreign currency risk exposure and the foreign denominated debt level have a significant positive relationship. Therefore, debt can be used as a hedge. However, a negative relationship exists between the foreign-denominated debt and the foreign currency derivative. Consequently, this is also an indication of using foreign denominated debt as a hedge, which alternates to the reducing currency risk in terms of usage by the foreign currency derivative.

Hedging is also studied to discern the ideal strategy for hedging. Wang and Low (2003) provide one such strategy in which the best hedging strategy is given in terms of the relationship of other factors to the hedge (e.g., future of foreign currency denominated stock index, equity interdependence, futures, markets of foreign exchange). These factors play a vital role in designing the best strategies for hedging. Contemporary investors also use future contracts to expand hedging, regardless of their type, as is portrayed in the Singapore Exchange given in the traded MSCI (Note 2) Taiwan index futures.

The scope of the exchange rate hedging literature is very broad. It encompasses within itself many facets that involve hedging and protection measures to be applied by firms for maintaining their existence in their market. One strategy that does not rely on hedging instruments is 'pass through.' Companies adopt different methods to 'pass through' changes in exchange rates into foreign prices; as a result of their 'exposure' to exchange rates their profits have to be adjusted accordingly. As prices lead to a change in profitability, a company's pass through and exposure should be related. Bodnar, Dumas and Marston (2002) demonstrate that pass through can have an effect on the exchange rate exposure because companies with inelastic demand can pass the changes in price on to the end user. The question of exchange rates affecting the price level is again a popular one among research methods according to Barhoumi (2006). This application is called exchange rate pass through because it informs how much of the exchange rate impact is passed through changes in the price. Donnenfeld and Zilcha (1991) found that using the technique of invoicing in the consumer's currency results in higher profits, bigger output and lower prices as compared to billing in the exporter's currency.

\subsection{Exchange Rate Exposure of Firms in Developing Countries}

A number of studies have investigated the foreign exchange exposure of firms operating in domestic companies. Kiymaz (2003) found that Turkish companies are greatly exposed to currency risk. The level of exposure is particularly intensified for textile, machinery, chemical and financial institutions. In addition, companies with greater levels of export and import participation are at an increased risk compared to companies with limited participation. In a more general study, Thirunavukkarasu (2006) attempted to understand the exposure risk of Emerging Market Multinationals (EMNCs) compared to that of the developed market multinationals (DMNCs). It was found that almost $60 \%$ of multinational companies in the sample were acutely exposed to exchange rate movements and that the EMNCs are more severely affected than DMNC by exchange rate movements. A number of other studies examine the economic impact of exchange rate fluctuations. However, few of them focus on the exposure of firms, especially domestic firms, and the UAE has not figured prominently in the existing studies.

\subsection{Gaps in the Literature}

After reviewing the literature, the following gaps have been identified:

1. This study contributes to a growing literature in international economics that provide compelling evidence that it is important to consider the effects of foreign exchange rate through competition on the value of domestic firms. Until now the empirical work that examine the effect of exchange rates on the value of firms has not considered the effect of foreign exchange rate on the value of domestic firms through their competition in developing countries.

2. The existing investigations into the exchange rate exposure of domestic corporations use measurements of 'competition' that have been questioned in the literature.

3. The existing literature does not contain an investigation into the exchange rate exposure of domestic corporations in the UAE. 
4. Aggarwal and Harper (2010) recommend further study of the nature and effects of foreign exchange exposure on domestic corporations. Moreover, Williamson (2001) undertook further study into exchange rate exposure and the competitive aspects of industry structures. This study aims to contribute positively on these points and take some steps toward filling the gaps that exist in the literature.

\section{Exchange Rates, Purchasing Power Parity and Competition}

With the move to flexible exchange rates in the early 1970s, is generally assumed that the exchange rate would quickly adjust to change in relative price levels (Lan 2001). The theory of purchasing power parity (PPP) is one of the fundamental principles in international finance. The PPP theory of the exchange rate looks at the relationship between a country's foreign exchange rate and its price level, as well as the relationship between changes in those variables (Allen \& Gandiya 2004).

The purchasing power parity (PPP) is the exchange rate between two currencies that would equate the two relevant national price levels if expressed in a common currency at that rate; the purchasing power of a unit of one currency would be the same in both economies. This concept of PPP is often termed absolute PPP. Relative PPP is said to hold when the rate of depreciation of one currency relative to another matches the difference in aggregate price inflation between the two countries concerned (Lan 2001). If the nominal exchange rate is defined simply as the price of one currency in terms of another, then the real exchange rate is the nominal exchange rate adjusted for relative national price level differences. When PPP holds, the real exchange rate is a constant, so that movements in the real exchange rate represent deviations from PPP. Hence, a discussion of the real exchange rate is tantamount to a discussion of PPP (Sarno \& Taylor 2002).

The relative PPP theory focuses on the change over time in the relative prices of trade baskets of similar goods and services in two countries. At any given time, the exchange rate between the two currencies is related to the rate of change in the price of the similar market baskets. According to relative PPP theory, as prices change in one country relative to those prices in another country for a traded basket of similar goods and services, the exchange rate will tend to change proportionately but in the opposite direction.

The rationale for this theory is that if one country experiences rising prices while its international trading partners do not, its exports will become less competitive. Similarly, imports will become more attractive because of their relatively lower prices. The exchange rate will change as citizens purchase currency of the country with falling prices and sell the currency of the country with rising prices (Gallagher \& Andrew 2000).

The volatility occurs for both nominal and real exchange rates. Real exchange rate changes translate into deviations from PPP which, for a domestic firm with local competitors, should have a direct effect on firm value. A local competitor is a firm that faces substantial foreign and domestic competition. In the simple case of an exporter with costs denominated in its home currency and sales in a local market with local competition, the firm's cash flows will be affected by changes in foreign currency. The sensitivity of a firm's cash flow in its home currency to changes in exchange rates is primarily a function of the elasticity of demand for a firm's product. Therefore, the first of those revenue exposures is the exposure of the corporation to change in its revenues resulting from a change in demand. The assumption is that a firm facing high levels of foreign and local competition will also face high demand elasticity. Therefore, a useful test for the existence of exchange rate would employ a sample of firms that have both high levels of local sales and face foreign and local competition (Williamson 2001).

To evaluate the effect of an exchange rate shock on the value of a firm, the firm should identify those shocks that are permanent and unanticipated. Firms selling and purchasing domestically may be exposed to changes in exchange rates via competition or economic exposure. As Lessard and Lightstone (1986) have observed, firms do not need foreign activity to have currency exposure; they need only more foreign competition in their home markets. The relative exposure to the change in the competitors' home currency is estimated by the rate in the home country of the competitors. If the firm is a simple exporter and denominates costs in local currency as well as selling in a local market with foreign and domestic competitors, the value of the firm in this case will be affected by a change in the exchange rate.

In spite of the absence of foreign assets or liabilities in the sample in this study, a nominal change in exchange rates if offset by a change in the price level in two countries should affect the real value of the firm. This offsetting effect of the price level with the exchange rate change would be consistent with the existence of purchasing power parity. Therefore, the exchange rate change that should determine the effect of a rate change on firm value is the real exchange rate change. The real exchange rate change implies deviation from PPP condition. These deviations happen as a result of the competition between the firm and a result of the strength of demand and supply (e.g., wage, inflation and cost of final goods). 
These deviations create either a disadvantage or advantage for firms because if a corporation prices in a currency different from its competitors operating in the same markets or because its scale of operations differs from that of the competition in particular markets, this supposition is true even though it prices in the same currency as its market competitors. In this context, the important factor is the customers' perception of the price in particular markets. Two competitors may operate out of the same country; however, if they price in different currencies, currency volatility will alter their price competitiveness.

The cash flow of the firm in local currency relative to changes in the exchange rate is mainly a function of the elasticity of the demand for a company's product which, in turn, depends on the degree of competition in an industry. Therefore, the assumption is that if local and foreign competition exists, higher demand elasticity exists as well. To demonstrate the existence of exchange rate exposure, one would use sample firms that have a high level of local sales with a high level of foreign and domestic competition (Williamson 2001). Theoretically, we would expect a positive relationship between foreign exchange exposure and competition.

The literature and theoretical financial economics provides the basis for a formal model that can be used to address the following research question:

What are the determinants of the exchange rate exposure of domestic corporations in the UAE and what are the implications of this exposure for the market value of those corporations?

We can expect to find a significant relationship between each of our determinants of foreign exchange exposure (including competition) and the foreign exchange exposure of domestic UAE firms. This expectation can be confirmed (or rejected) by undertaking a formal analysis in which the degree of variation in the foreign exchange exposure of domestic UAE firms is explained by variation in each of our determinants (including competition). This formal analysis is described in the following section.

\section{Methodology}

\subsection{Sample of Non-financial Companies in the UAE}

The type of companies must be defined to identify the companies as subjects for this research. Domestic firms in this study may be defined as only those firms with sales and purchases on the local market. Some firms may also come under the genre of domestic companies that purchase their goods from a wholesaler or a supplier from foreign countries and, therefore, may have indirect exposure to foreign exchange rates.

The sample of this study is selected from the Emirates Securities Market and OSIRIS - publicly listed companies worldwide. The total firms in this research registered in the market are 133 according to the UAE market for securities and Osiris program. This study covers all domestic non-financial firms in the market. Therefore, the sample of companies used in this research excludes banks, financial firms or insurance firms.

Only firms which provided complete data for the 7 year period were included in the research. This method led to the selection of 49 non-financial firms of UAE domestic firms. Data for the period from January 2005 to December 2011 was used on a monthly and quarterly basis. Therefore, the total number of companies yielding insufficient information is 31 .

Table 1. Sample selection of firm

\begin{tabular}{|c|c|c|}
\hline Emirates Securities Market firms & Number of firms include & Total number of firms \\
\hline Total number of extracted firms from the market & & 133 \\
\hline Financial companies & -25 & 108 \\
\hline Insurance companies & -28 & 80 \\
\hline Total number of companies that yielded information & -31 & 49 \\
\hline Total number of firms qualified for final inclusion & & 49 \\
\hline
\end{tabular}

\subsection{Data Analysis}

This study uses Eviews program to analyse data collection. In addition, the method used to analyse the data and generate results may be summarised as follows: 
a. A two-factor market model will be used to determine the exchange rate exposure for each firm in the sample. This is depicted in Equation (1) below.

b. The values for the residual exchange exposure in Equation (1) become the dependent variable for the multivariate regressions undertaken in the subsequent steps of the analysis.

c. Drawing on the literature to identify determinants of exchange exposure (independent variables in Equation (2)), the analysis proceeds to estimate a multivariate regression Equation (2) for a sample of domestic UAE firms.

d. The results of the regression analysis will provide an indication of the nature of foreign exchange exposure of domestic UAE firms.

This study will employ a regression model inferred from Jorion (1991). The analysis starts with a two-factor model: (1) the return on the market index is the first factor; and (2) the second factor is the exchange rate changes. To test the relationship between foreign exchange rate exposure for firms and the average of the appropriate financial variables for the period of study for each firm, this study employs the following regression model for ten economic factors postulated inferred from Aggarwal and Harper (2010), and the component of the exchange rate as the eleventh factor with some modification in this model. To measure foreign exchage exposure, this study draws on the two factor model, based on Jorion (1991), the exchange rate, and a market index as an independent variable.

$$
R_{i, t}=a+\beta_{i} R_{m, t}+\gamma_{i} X R_{j, t}+\varepsilon_{i}
$$

From the equation (1) where: $\alpha$ is the constant term; $R_{i, t}$ is the return of firm $\mathrm{i}$, over time period $\mathrm{t}$; $R_{m, t}$ is the return on the market index; $X R_{j, t}$ is the exchange rate change of currency or currency index that represent six currencies used in this study $j$ over time period $t$; and $\gamma$ measures the firm's residual foreign exchange exposure to the foreign exchange exposure of the market. This study investigated the impact of foreign exchange rates on a monthly basis. Due to the exposure of foreign exchange rate the impact comes from the competitive situation and is primarily indirect. The average monthly foreign exchange rate (Europe euro, Japanese yen, UK pound, Australian dollar, and Indian rupee currencies, as well as equally weighted exchange rate) will be used to determine its impact on the return for the full sample of firms. The measures of change in exchange rate coefficients will provide the relationship to the index through the effect of the exchange rate on stock return.

$$
\begin{gathered}
R_{i, t}=a+\beta_{i} R_{m, t}+\gamma_{i} G B P_{j, t}+\varepsilon_{i} \\
R_{i, t}=a+\beta_{i} R_{m, t}+\gamma_{i} E U R_{j, t}+\varepsilon_{i} \\
R_{i, t}=a+\beta_{i} R_{m, t}+\gamma_{i} J P Y_{j, t}+\varepsilon \\
R_{i, t}=a+\beta_{i} R_{m, t}+\gamma_{i} A U D_{j, t}+\varepsilon_{i} \\
R_{i, t}=a+\beta_{i} R_{m, t}+\gamma_{i} I N D_{j, t}+\varepsilon \\
R_{i, t}=a+\beta_{i} R_{m, t}+\gamma_{i} E Q W_{j, t}+\varepsilon_{i}
\end{gathered}
$$

The motivation in choosing this model is that the exchange rate risk in this model is the residual risk after the control of the market's own exchange rate exposure. In addition, this model is the most preferred approach by researchers to measure the exposure of foreign exchange (Bodnar \& Wong 2003). Ordinary least squares are used for the equations $(2-7)$ to obtain the exposure of exchange rate coefficients for the study sample.

To test the relationship between foreign exchange rate exposure for firms and the financial and operational variables (the determinants of foreign exchange rate) that influence a firm's ability to reduce exposure, this study employs the following regression model drawn from Aggarwal and Harper (2010) with some modifications. This study added return on equity (ROE), price cost margins (PCM) and gross margin. 


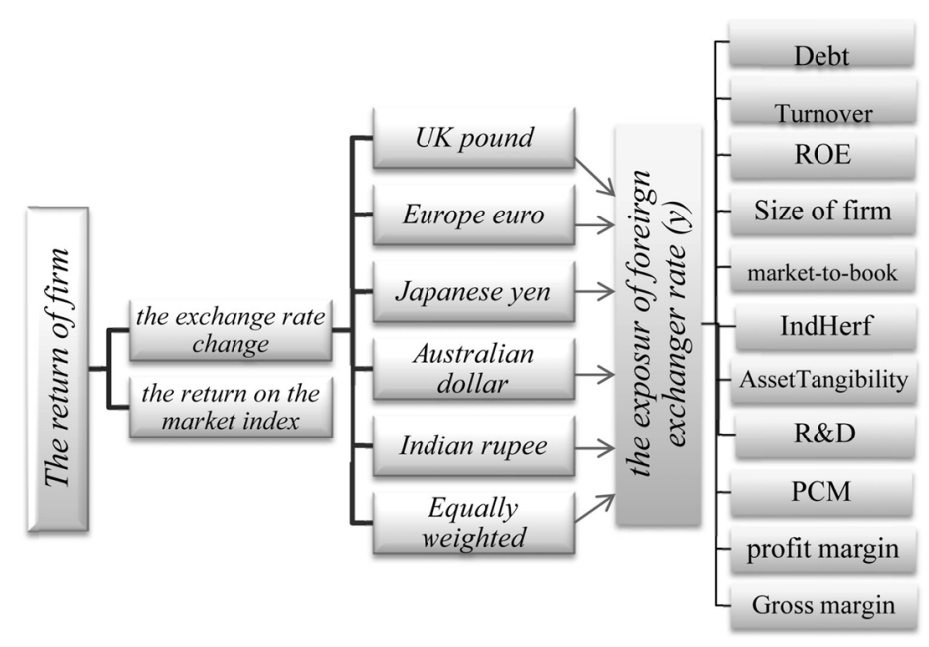

Figure 1. Conceptual model of Factors Affecting The return of firms

$$
\begin{gathered}
\left|\hat{\gamma}_{i}\right|=\alpha+\beta_{1} \text { Debt }+\beta_{2} \text { Turnover }+\beta_{3} \text { ROE }+\beta_{4} \text { Size }+\beta_{5} \text { MkBk }+\beta_{6} \text { IndHerf }+\beta_{7} \text { AssetTangibility }+\beta 8 \text { R\&D }+ \\
\beta_{9} \text { PCM }+\beta_{10} \text { profit margin }+\beta_{11} \text { Gross margin } \sum_{j=2}^{n} b_{i} \operatorname{SIC}_{\mathrm{j}}+\varepsilon
\end{gathered}
$$

where Debt $=$ the average debt ratio, Turnover $=$ the average asset turnover, the Turnover represents the amount of sales generated for each currency's worth of assets. Size $=$ the averaged log equity market value of the firm. This study has avoided the average gross profit margin, which has insignificant exposure and is not related to industry competitive structures in the study of Aggarwal and Harper (2010), and replaced it with (ROE). $\mathbf{R O E}=$ Return on Equity. The amount of net income is returned as a percentage of shareholder equity. This metric can be used to compare a company with its competitors and is also useful for comparing the profitability of a company to that of other firms in the same industry. $\mathbf{M k B k}=$ the average market-to-book ratio, a ratio used to find the value of a company by comparing the book value of a firm to its market value, and AssetTangibility $=$ the average long-term assets to total assets ratio, and the long-term assets represent the value of a company's property, equipment, and other capital assets, such as stocks, bonds or other assets that an investor plans to hold for a long period of time. IndHerf = the average industry Herfindahl index, a factor that usually measures market concentration. It is calculated by squaring the market share of each firm competing in a market, which captures information about the number of firms in the industry and the distribution of their market shares. In addition, research and development $(R \& D)$ is a segment of any corporation ( $R \& D / S a l e s)$. Determining the degree of $\mathbf{R} \& \mathbf{D}$ is important to determine the degree of competition. R\&D is defined as discovery of new products or development of new products. Moreover, the R\&D investments reduce the exposure of any firm to the foreign exchange rates. Therefore, $R \& D$ expenses enable a firm to avoid experiencing exchange rate variations. In addition, the insulation of a firm from both foreign and local competition depends on the firm's desire to invest in unique services and products.

Price cost margins (PCM) is an important indicator of the competitiveness of the market and the market power in any country because it determines the difference in the price and the marginal cost of the goods that are traded in the market. Profit margin, is the ratio of profitability calculated as net income divided by revenue, or net profits divided by sales. It measures how much out of every dollar of sales a company actually keeps in earnings. Profit margin is very useful when comparing companies in similar industries. A higher profit margin indicates a more profitable company that has better control over its costs compared to its competitors. Gross margin is a company's total sales revenue minus its cost of goods sold, divided by the total sales revenue, expressed as a percentage. The gross margin represents the percent of total sales revenue that the company retains after incurring the direct costs associated with producing the goods and services sold by a company. The higher the percentage, the more the company retains of each dollar of sales to service its other costs and obligations. The final factor is a dummy variable (SICj), which is usually evaluated by the financial analysts for almost all companies prevailing in the economic market. Nevertheless, the most critical aspect of exchange rates is that 
firms operating in industries like petrochemicals and other manufacturing and production firms will experience considerable fluctuations and respective exchange service firms will be swayed much less by the global implications of the international economy.

Market share: Market share is the firm's sales divided by total industry sales,

$$
s_{i}=\frac{y_{i}}{\sum_{i} y_{i}}
$$

Where $\mathrm{y}^{i}=\mathrm{p}_{\mathrm{i}} \mathrm{q}_{\mathrm{i}}$, is firm revenues.

Herfindahl: It is calculated on the sum of the squared market shares, which captures information about the number of firms in the industry and the distribution of their market shares.

$$
H=\sum_{i} s_{i}^{2}
$$

Price cost margins (PCM) is an important indicator of the competitiveness of the market and the market power in any country because it determines the difference in the price and the marginal cost of the goods that are traded in the market.

Price-cost margin: The weighted (by market share) price-cost margin, or the gross profit margin, is

$$
P C M=\sum_{i} s_{i} \frac{y_{i}-T V C_{i}}{y_{i}}
$$

Where $i$ indexes firms and $\mathrm{TVC}^{i}=c_{i} q_{i}$ is total variable costs to the firm, which includes labour and intermediate costs.

Equation (8) is estimated for a sample of all firms. The goal of these cross-sectional regressions, using the full sample of domestic firms or the firms with statistically significant estimated exposures, is to determine what causes variations in foreign exchange exposure among firms. The estimated parameter $(\varepsilon)$ indicates that some firms have positive exposure, whereas others exhibit negative exposure. To explain the determinants of the absolute size of the exposures, the regression model is estimated using the absolute value of $(\varepsilon)$.

\section{References}

Aabo, T., Høg, E., \& Kuhn, J. (2010). Integrated foreign exchange risk management: The role of import in medium-sized manufacturing firms. Journal of Multinational Financial Management, 20(4-5). http://dx.doi.org/10.1016/j.mulfin.2010.08.002

Abor, J. (2005). Managing foreign exchange risk among Ghanaian firms. Journal of Risk Finance, 6(4). http://dx.doi.org/10.1108/15265940510613642

Aggarwal, R., \& Harper, J. T. (2010). Foreign exchange exposure of "domestic" corporations. Journal of International Money and Finance. In Press, Corrected Proof. http://dx.doi.org/10.1016/j.jimonfin.2010.05.003

Allayannis, G., \& Ofek, E. (1997). Exchange rate exposure, hedging, and the use of foreign currency derivatives. New York University Virginia.

Allayannis, G., Ihrig, J., \& Weston, J. (2001). Exchange-rate hedging: Financial versus operational strategies. American Economic Review, 91(2). http://dx.doi.org/10.1257/aer.91.2.391.

Allen, D., \& Gandiya, F. (2004). Assessing exchange rate hypothesis within Southern Africa. Ashgate Pub Ltd.

Barhoumi, K. (2006). Differences in long run exchange rate pass-through into import prices in developing

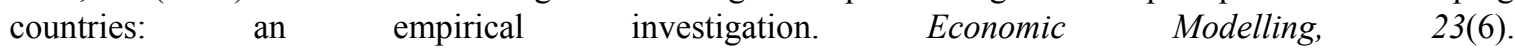
http://dx.doi.org/10.1016/j.econmod.2006.04.006.

Bartov, E., \& Bodnar, G. (1994). Firm valuation, earnings expectations, and the exchange-rate exposure effect. Journal of Finance, 49(5). http://dx.doi.org/10.1111/j.1540-6261.1994.tb04780.x.

Bartram, S, Brown, G., \& Minton, B. (2010). Resolving the exposure puzzle: The many facets of exchange rate exposure. Journal of Financial Economics, 95(2), 148-73. http://dx.doi.org/10.1016/j.jfineco.2009.09.002.

Bartram, S. (2008). What lies beneath: Foreign exchange rate exposure, hedging and cash flows. Journal of Banking \& Finance, 32(8). http://dx.doi.org/10.2139/ssrn.905087 
Bodnar William, M., \& Gordon, M. (1993). Exchange rate exposure and industry characteristics: Evidence from Canada, Japan, and the USA. Journal of International Money and Finance, 12(1). http://dx.doi.org/10.1016/0261-5606(93)90008-Y

Bodnar, G. (1995). Foreign currency translation reporting and the exchange-rate exposure effect. Journal of International Financial Management \& Accounting, 6(2), 93-114.

Bodnar, G. M., \& Wong, M. H. F. (2003). Estimating exchange rate exposures: Issues in model structure. Financial Management, 32(1). http://dx.doi.org/10.2307/3666203

Bodnar, G., Dumas, B., \& Marston, R. (2002). Pass through and Exposure. The Journal of Finance, 57(1). http://dx.doi.org/10.1111/1540-6261.00420

Bradley, K., \& Moles, P. (2001). The effects of exchange rate movements on non-financial UK firms. International Business Review, 10(1), 51-69. http://dx.doi.org/10.1016/S0969-5931(00)00041-X

Choi, J., \& Prasad, A. (1995). Exchange risk sensitivity and its determinants: A firm and industry analysis of US multinationals. Financial Management, 24(3). http://dx.doi.org/10.2307/3665559

CIA. (2011). The World Factbook, Central Intelligence Agency (CIA), viewed June 26.

Darrat, A. F., \& Al-Yousif, Y. K. (2003). Monetary Dynamics Of Inflation: Some Evidence for A Small Open Econoi.

De Jong, A., Ligterink, J., \& Macrae, V. (2006). A firm-specific analysis of the exchange-rate exposure of Dutch firms. Journal of International Financial Management and Accounting, 17(1). http://dx.doi.org/10.1111/j.1467-646X.2006.00119.x

Doidge, C., Griffin, J., \& Williamson, R. (2002). Does exchange rate exposure matter. Ohio State University.

Dominguez, K., \& Tesar, L. (2006). Exchange rate exposure. Journal of international Economics, 68(1), 188-218. http://dx.doi.org/10.1016/j.jinteco.2005.01.002

Donnenfeld, S., \& Zilcha, I. (1991). Pricing of exports and exchange rate uncertainty. International Economic Review, 32(4). http://dx.doi.org/10.2307/2527048

Elliott, W., Huffman, S., \& Makar, S. (2003). Foreign-denominated debt and foreign currency derivatives: complements or substitutes in hedging foreign currency risk?. Journal of Multinational Financial Management, 13(2), 123-39. http://dx.doi.org/10.1016/S1042-444X(02)00039-7

El-Masry, A (2006). The exchange rate exposure of UK nonfinancial companies: industry level analysis. Managerial Finance, 32(2). http://dx.doi.org/10.1108/0307435061064190

Fraser, S., \& Pantzalis, C. (2004). Foreign exchange rate exposure of US multinational corporations: a firm-specific approach. Journal of Multinational Financial Management, 14(3). http://dx.doi.org/10.1016/j.mulfin.2003.07.008

Froot, K., Scharfstein, D., \& Stein, J. (1993). Risk management: Coordinating corporate investment and financing policies. Journal of Finance, 48(5), 1629-58.

Gallagher, T., \& Andrew, J. (2000). Financial management: principles and practice. Prentice Hall.

Gao, T. (2000). Exchange rate movements and the profitability of US multinationals. Journal of International Money and Finance, 19(1). http://dx.doi.org/10.1016/S0261-5606(99)00038-8

Géczy, C., Minton, B., \& Schrand, C. (1997). Why firms use currency derivatives. Journal of Finance, 52(4). http://dx.doi.org/10.1111/j.1540-6261.1997.tb01112.x

He, J., \& Ng, L. (1998). The foreign exchange exposure of Japanese multinational corporations. The Journal of Finance, 53(2). http://dx.doi.org/10.1111/0022-1082.295575

Jong, A., Ligterink, J., \& Macrae, V. (2006). A firm-specific analysis of the exchange-rate exposure of Dutch firms. Journal of International Financial Management \& Accounting, 17(1).

Jorion, P. (1990). The exchange-rate exposure of US multinationals. Journal of Business, 63(3). http://dx.doi.org/10.1086/296510

Jorion, P. (1991). The pricing of exchange rate risk in the stock market. Journal of Financial and Quantitative Analysis, 26(03). http://dx.doi.org/10.2307/2331212

Kiymaz, H. (2003). Estimation of foreign exchange exposure: an emerging market application. Journal of Multinational Financial Management, 13(1). http://dx.doi.org/10.1016/S1042-444X(02)00034-8 
Kolasa, M., Rubaszek, M., \& Taglioni, D. (2010). Firms in the great global recession: The role of foreign ownership and financial dependence. Emerging Markets Review, 11(4). http://dx.doi.org/10.1016/j.ememar.2010.06.001

Lan, Y. (2001). The explosion of purchasing power parity. Dept. of Economics University of Western Australia, Nedlands, W.A.

Lessard, D., \& Lightstone, J. (1986). Volatile exchange rates can put operations at risk. Harvard Business Review, 64(4), 107-14,

Luehrman, T. (1990). The exchange rate exposure of a global competitor. Journal of International Business Studies, 21(2). http://dx.doi.org/10.1057/palgrave.jibs.8490333

Marston, R. (2001). The effects of industry structure on economic exposure. Journal of International Money and Finance, 20(2). http://dx.doi.org/10.1016/S0261-5606(00)00052-8

Melvin, M., \& Taylor, M. (2009). The crisis in the foreign exchange market. Journal of International Money and Finance, 28(8). http://dx.doi.org/10.1016/j.jimonfin.2009.08.006

E., Mohamad, SNE, F., Mitra , G., Mangal, \& F., Holger. (2005). International Monetary Fund The United Arab Emirates, Washington, D.C.

Muller, A., \& Verschoor, W. (2006). Foreign exchange risk exposure: Survey and suggestions. Journal of Multinational Financial Management, 16(4). http://dx.doi.org/10.1016/j.mulfin.2005.09.001

Opler, T., \& Titman, S. (1994). Financial distress and corporate performance. Journal of Finance, 49(3). http://dx.doi.org/10.1111/j.1540-6261.1994.tb00086.x

Pantzalis, C., Simkins, B., \& Laux, P. (2001). Operational hedges and the foreign exchange exposure of US multinational corporations. Journal of International Business Studies, 32(4). http://dx.doi.org/10.1057/palgrave.jibs.8490995

Parsley, D., \& Popper, H. (2006). Exchange rate pegs and foreign exchange exposure in East and South East Asia. Journal of International Money and Finance, 25(6). http://dx.doi.org/10.1016/j.jimonfin.2006.07.009

Sala-i-Martin, X., Blanke, J., Hanouz, M. D., Geiger, T., \& Mia, I. (2010). The Global Competitiveness Index 2010-2011: Looking Beyond the Global Economic Crisis. The Global Competitiveness Report, 2011, 14-80.

Salifu, Z., Osei, K., \& Adjasi, C. (2007). Foreign exchange risk exposure of listed companies in Ghana. Journal of Risk Finance, 8(4). http://dx.doi.org/10.1108/15265940710777324

Sarno, L., \& Taylor, M. (2002). Purchasing Power Parity and the Real Exchange Rate. IMF Staff Papers, 49(1). $65-106$,

Shapiro, A. (1975). Exchange rate changes, inflation, and the value of the multinational corporation. Journal of Finance, 30(2). http://dx.doi.org/10.1111/j.1540-6261.1975.tb01824.x

Thirunavukkarasu, A. (2006). Exchange rate fluctuation and firm value analysis of emerging market multinationals. Southern New Hampshire University.

Wang, C., \& Sern Low, S. (2003). Hedging with foreign currency denominated stock index futures: evidence from the MSCI Taiwan index futures market. Journal of Multinational Financial Management, 13(1). http://dx.doi.org/10.1016/S1042-444X(02)00020-8

Williamson, R. (2001). Exchange rate exposure and competition: evidence from the automotive industry* 1. Journal of Financial Economics, 59(3). http://dx.doi.org/10.1016/S0304-405X(00)00093-3

\section{Notes}

Note 1. A free trade zone (FTZ) or export processing zone (EPZ) is an area of a country where some normal trade barriers such as tariffs and quotas are eliminated and bureaucratic requirements are lowered in hope of attracting new business and foreign investments. In addition, it is a region where a group of countries has agreed to reduce or eliminate trade barriers.

Note 2. MSCI (Morgan Stanley Capital International) is a leading provider of investment decision support tools to investors globally, including asset managers, banks, hedge funds and pension funds. 